\title{
Morfologi Hemipenis Biawak Air (Varanus salvator bivittatus)
}

\section{Morphology of the Hemipenes of Water Monitor lizard (Varanus salvator bivittatus)}

\author{
Mahfud $^{1}$, Adi Winarto ${ }^{2}$, Chairun Nisa ${ }^{2}$ \\ ${ }^{1}$ Program Studi Pendidikan Biologi, Fakultas Keguruan dan Ilmu Pendidikan, \\ Universitas Muhammadiyah Kupang \\ Jl. KH. Ahmad Dahlan No. 17 Walikota Kupang-NTT, 82558 \\ Email : mahfud.aph@gmail.com \\ ${ }^{2}$ Bagian Anatomi, Histologi dan Embriologi, Fakultas Kedokteran Hewan, Institut Pertanian Bogor \\ J1. Agatis Kampus IPB Dramaga Bogor 16680 \\ Email : winawyn@yahoo.com,4chnisa@yahoo.com
}

\begin{abstract}
Varanus salvator bivittatus has a pair of hemipenes, which is macroscopic anatomically like the copulatory organ in other amniotes, cylindrical-shaped (truncus) with quite flexible, and it located on the base of the caudal tail of the cloaca. However, information about the microscopic anatomy of hemipenes of this animal is scientifically unpublicized. Therefore, the aim of this research is to study the microscopic anatomy of hemipenes of male Varanus salvator bivittatus. The animals were sacrificed by exsanguination under deep anesthetized and fixed in $4 \%$ paraformaldehyde through perfusion then observed visceral site and morphometric. Histomorphological evaluation was obtained by paraffin preparation with section thickness of 3-4 $\mu \mathrm{m}$ then stained in Hematoxylin-Eosin (HE) and Masson's Trichrome (MT). The results showed that truncus of hemipenes was lined by stratified squamous epithelium and supported with thick of dense connective tissue and contain cavernous body and blood vessels are found, the muscles not found. The presence of connective tissue that supported in the down part sometimes make hemipenes are rigid while prurient condition. In the caudal of truncus hemipenes there is retractor muscle of hemipenes which arranged by striated muscles. Hemipenes is flexible because contain with much of blood vessel that found in truncus hemipenes.
\end{abstract}

Keyword: Varanus salvator bivittatus, hemipenes, morphology.

\begin{abstract}
Abstrak
Hemipenis biawak Varanus salvator bivittatus secara morfologi seperti organ kopulatori pada amniota lainnya, berjumlah sepasang, berbentuk silinder (truncus) yang cukup fleksibel dan terletak di pangkal ekor kaudal dari kloaka. Sejauh ini publikasi ilmiah mengenai struktur mikroskopis hemipenis hewan ini belum ditemukan. Oleh Karena itu, penelitian ini bertujuan untuk mempelajari morfologi hemipenis Varanus salvator bivittatus jantan, baik secara makroskopis maupun mikroskopis. Dua ekor biawak jantan dewasa yang digunakan dalam penelitian ini dianestesi, dilakukan exanguinasi, dan difiksasi dengan paraformaldehid $4 \%$ secara perfusi. Sampel jaringan untuk sediaan histologis dibuat dengan metoda parafin. Blok parafin disayat dengan ketebalan 3-4 $\mu \mathrm{m}$, diwarnai dengan hematoxylin eosin (HE) dan Masson's trichrome (MT). Hasil pengamatan menunjukkan bahwa mukosa truncus hemipenis dilapisi oleh epitel pipih banyak lapis, ditunjang oleh jaringan ikat padat yang di bawahnya ditemukan corpus cavernous dengan banyak pembuluh darah, namun tidak ditemukan adanya otot. Corpus cavernous dengan banyak pembuluh, menyebabkan hemipenis ini bersifat mudah membesar, namun kaku karena ditopang oleh jaringan ikat padat. Bagian kaudal truncus hemipenis terdapat otot retraktor hemipenis yang disusun oleh otot lurik.
\end{abstract}

Kata Kunci: Varanus salvator bivittatus, truncus hemipenis, morfologi. 


\section{Pendahuluan}

Varanus salvator bivittatus adalah subspesies dari Varanus salvator atau yang dikenal dengan biawak air. Hewan ini merupakan subspesies biawak endemik Indonesia yang hanya ditemukan di Jawa (Canto, 2007), Bali dan Nusa Tenggara (keculai Pulau Timor) (Shine et al., 1996).

Biawak air termasuk kategori Appendiks II dalam daftar CITES (The Convention on International Trade in Endangered Species of Wild Fauna and Flora) (Gumilang dkk., 2003). Hal ini berarti biawak air dapat diperdagangkan di pasar internasional dengan kuota yang telah ditetapkan. Hasil survei menunjukkan bahwa lebih dari satu juta biawak $V$. salvator diambil dari alam setiap tahun untuk dibunuh dan dikuliti, dengan jumlah terbesar berasal dari Indonesia, khususnya Sumatera dan Kalimantan (Jenkins and Broad, 1994). Jika eksploitasi V. salvator terus terjadi, akan mengakibatkan penurunan jumlah populasi hewan ini di alam dan tidak menutup kemungkinan $V$. salvator akan dikategorikan dalam Appendiks I CITES seperti halnya pada $V$. komodoensis.

Populasi liar V. s. bivittatus di alam diduga semakin berkurang, sementara informasi ilmiah mengenai hewan ini, khususnya yang berkaitan dengan sistem organ tubuhnya masih sangat sedikit dilaporkan. Publikasi ilmiah mengenai sistem organ masih terbatas pada anatomi makroskopis organ reproduksi jantan (Mahfud dkk., 2015). Sejauh ini, informasi mengenai morfologi organ reproduksi masih didominasi oleh reptil jenis lain, misalnya pada kura-kura Phrynops geoffroanus (Cabral et al., 2011), ular Seminatrix pygaea (Sever, 2004), ular Bittis arietans arietans (Karim, 1998), ular Crotalus durissus terrificus (Porto et al., 2013), dan biawak Varanus marmoratus (Prades et al., 2013).
Salah satu keunikan yang terdapat pada organ reproduksi $V$. s. bivittatus jantan seperti yang dilaporkan (Mahfud dkk., 2015) adalah memiliki sepasang hemipenis. Hemipenis (seperti halnya penis pada mamalia) adalah organ seksual pada biawak yang digunakan sebagai organ kopulatori (Kardong, 2008), yang juga terdapat pada kelompok squamata lainnya. Hemipenis digunakan secara bergantian ketika kawin dengan biawak betina dan biasanya hanya salah satu yang digunakan untuk kopulasi (MNH, 2009). Sepasang hemipenis hewan ini tersimpan di pangkal ekor kaudal dari kloaka (Mahfud dkk 2015), yang menyebabkan bentuk ekor biawak jantan berbeda dibandingkan betina, sehingga dapat dijadikan sebagai salah satu ciri untuk menentukan jenis kelamin biawak (MNH, 2009).

Tulisan yang merupakan hasil penelitian ini dimaksudkan untuk memberikan informasi tentang morfologi hemipenis $V$. s. bivittatus jantan, baik secara makroskopis maupun mikroskopis, diharapkan dapat memberikan manfaat dalam memperkaya informasi biologi sistem reproduksi dari keanekaragaman hewan di Indonesia, serta dapat dijadikan sebagai acuan dalam penelitian-penelitian yang berhubungan dengan sistem reproduksi $V$. s. bivittatus untuk menunjang upaya konservasi ex situ.

\section{Materi dan Metode}

Penelitian ini menggunakan dua ekor biawak $V$. salvator bivittatus jantan dewasa dengan panjang $45.60 \pm 6.51 \mathrm{~cm}$ SVL dan berat $1.4 \pm 0.28 \mathrm{~kg}$ yang didapat dari wilayah Bogor pada tahun 2013. Hewan dianestesi dengan menggunakan kombinasi ketamin 50mg/kg BB dengan xylazine $10 \mathrm{mg} / \mathrm{kg}$ BB secara intramuskular. Saat hewan teranastesi, dilakukan proses pengeluaran darah (exanguinasi), 
yaitu dengan menyayat atrium kanan jantung dan memasukkan larutan $\mathrm{NaCl}$ Fisiologis 0,9\% menggunakan kanul ke ventrikel kiri jantung sampai cairan yang keluar dari atrium kanan jantung terlihat bening, selanjutnya dilakukan proses fiksasi dengan menggantikan larutan $\mathrm{NaCl}$ Fisiologis 0,9\% dengan larutan paraformaldehida $4 \%$ secara perfusi pada saat jantung masih berdenyut.

Pengamatan makroskopis dilakukan dengan mengeluarkan hemipenis dari pangkal ekor, dengan cara memasukkan air menggunakan spuit. Untuk pengamatan histologi, sampel jaringan untuk sediaan histologis menggunakan metode paraffin, disayat dengan ketebalan 3-4 $\mu \mathrm{m}$, dideparafinisasi dan rehidrasi, kemudian diwarnai dengan pewarnaan Hematoxylin dan Eosin (HE) (merupakan pewarnaan standar untuk mengetahui struktur umum sel maupun jaringan dalam suatu organ) dan Masson's trichrome (MT) (untuk mengetahui keberadaan jaringan ikat dalam suatu organ), mengacu pada Kiernan (1990), dilanjutkan dengan proses dehidrasi, clearing dan mounting. Hasil pewarnaan diamati dan difoto menggunakan mikroskop yang dilengkapi dengan alat fotografi (mikrofotografi). Pengamatan dilakukan untuk mengetahui struktur histologis hemipenis. Semua hasil pengamatan dan data yang diperoleh dianalisis secara deskriptif.

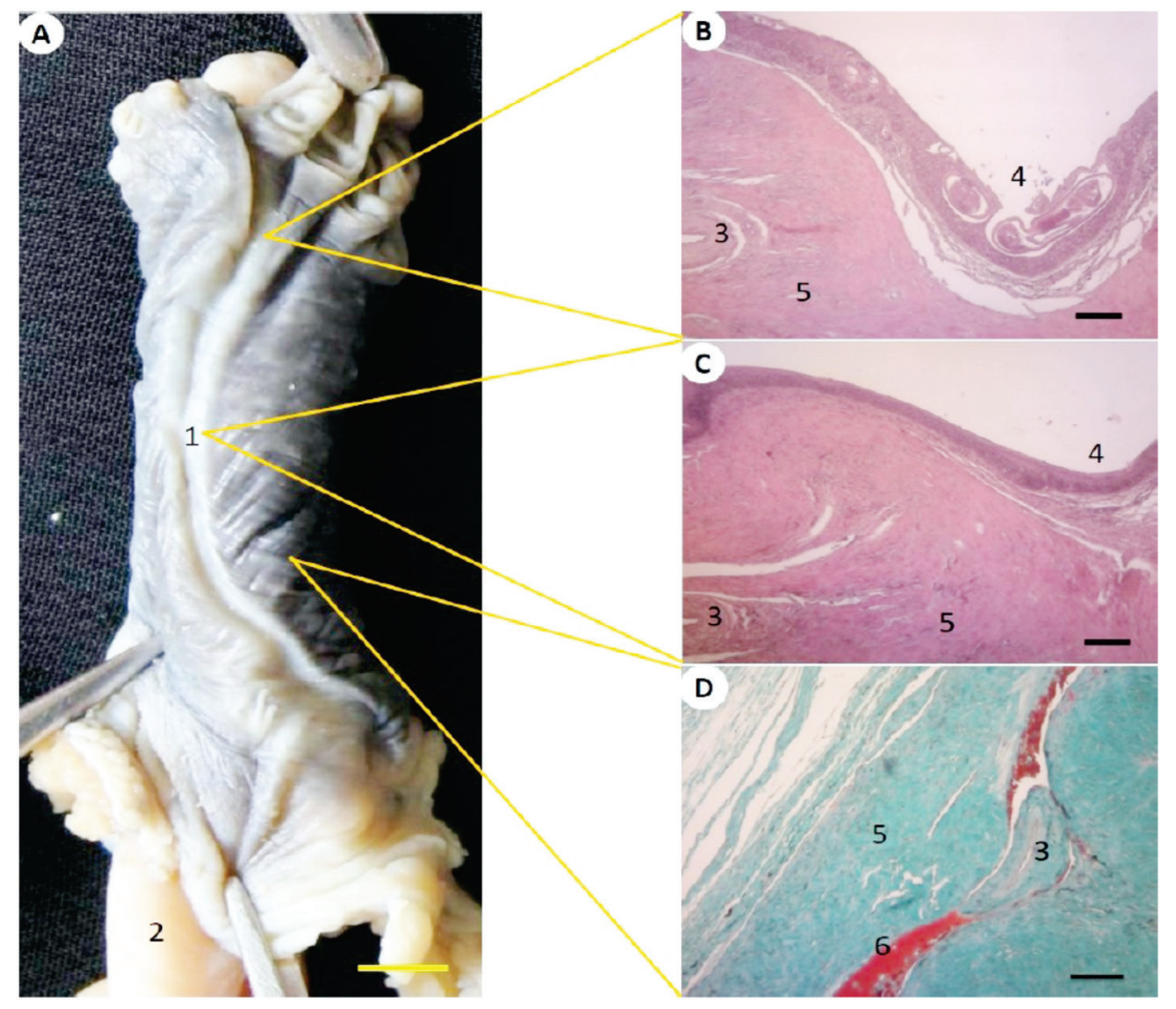

Gambar 1. Morfologi hemipenis biawak V. s. bivittatus. Hemipenis dalam kondisi ereksi ( $\mathrm{A}=$ Tampak Dorsal, $\uparrow$ arah kranial) (Mahfud dkk 2015); Gambaran histologi sayatan melintang jaringan hemipenis daerah kaput (B), medial (C) dan kaudal (D). 1. sulcus spermaticus, 2. otot retraktor, 3. pembuluh darah, 4. lekukan sulcus spermaticus, 5. corpus cavernous hemipenis yang disusun oleh jaringan ikat dengan serabut kolagen, 6 . eritrosit. Pewarnaan $B, C=H E, D=M T$. Bar: $\mathrm{A}=1 \mathrm{~cm}, \mathrm{~B}, \mathrm{C}, \mathrm{D}=100 \mu \mathrm{m}$. 


\section{Hasil dan Pembahasan}

Hemipenis $V$. s. bivittatus merupakan organ berongga berbentuk silinder (truncus) yang terletak di pangkal ekor kaudal dari kloaka (Gambar 1A) (Mahfud dkk., 2015). Truncus hemipenis dilapisi oleh epitel pipih banyak lapis yang didukung oleh jaringan ikat padat dan di bawahnya ditemukan corpus cavernous dengan cukup banyak pembuluh darah vena di dalamnya (Gambar 1B, 1C, 1D). Hal inilah yang menyebabkan truncus hemipenis hewan ini cukup fleksibel untuk membesar karena berisi darah sebelum kopulasi. Menurut Porto et al. (2013), adanya tekanan darah di dalam pembuluh darah corpus cavernous, menyebabkan hemipenis dapat melakukan ereksi dan pada saat yang sama otot propulsar mendorong hemipenis sampai terjadi kopulasi. Pembuluh darah ini bertanggung jawab untuk drainase darah dari hemipenis setelah terjadi kopulasi, sehingga hemipenis mengecil dan dapat ditarik masuk kembali ke ruangan di pangkal ekor.

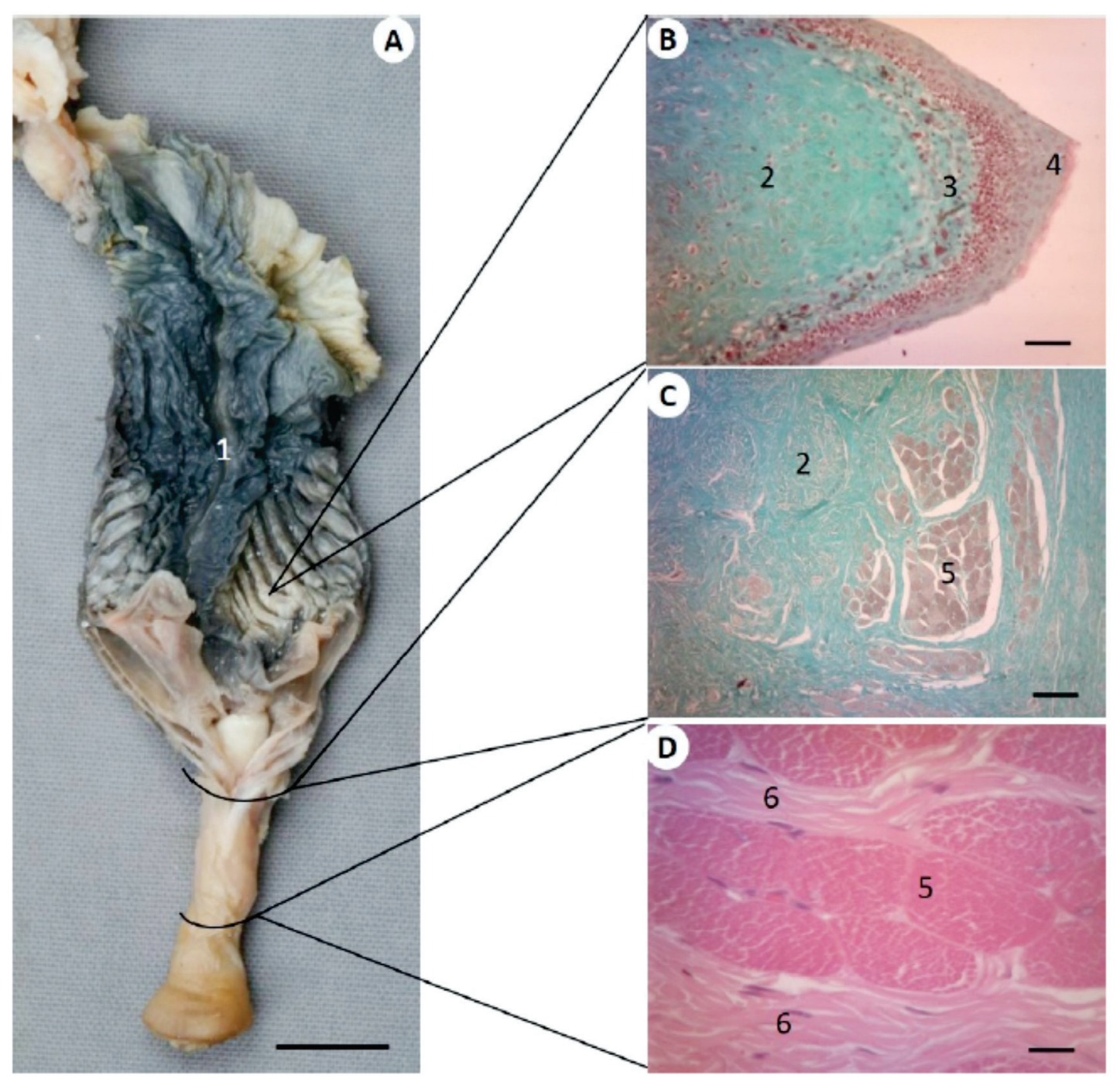

Gambar 2. Struktur bagian kaudal dan otot retraktor hemipenis biawak V. s. bivittatus dalam kondisi tidak ereksi ( $\mathrm{A}=$ tampak ventral, $\downarrow$ arah kaudal) (Mahfud dkk); Gambaran histologi sayatan melintang lipatan mukosa hemipenis (B), daerah penyatuan otot retraktor dengan hemipenis (C) dan otot retraktor (D). 1. sulcus spermaticus, 2. jaringan ikat dengan bentuk seperti tendon, 3. lamina propia, 4. epitel pipih banyak lapis, 5. otot retraktor yang disusun oleh otot lurik, 6. jaringan ikat longgar. Pewarnaan B, C $=$ MT, D = HE. Bar: A $=1 \mathrm{~cm}, \mathrm{~B}=50 \mu \mathrm{m}, \mathrm{C}=100 \mu \mathrm{m}, \mathrm{D}=10 \mu \mathrm{m}$. 
Bagian corpus cavernous banyak ditemukan pembuluh darah, akan tetapi tidak ditemukan adanya kelenjar dan otot polos (Gambar 1D). Hemipenis yang disusun oleh corpus cavernous tanpa otot polos juga ditemukan pada kura-kura $P$. geoffroanus (Cabral et al., 2011) dan ular Bittis arietans arietans (Karim, 1998). Hal ini berbeda pada ular Crotalus durissus terrificus (Porto et al., 2013) dan penis mamalia (Goldstein and Padma-Nathan, 1990) pada umumnya seperti pada Tamandua tetradactyla (Rossi et al., 2012), Trenggiling (Manis javanica) (Akmal, 2014), dan muncak (Muntiacus muntjak muntjak) (Wahyuni, 2012), bahwa sebagian besar parenkim corpus cavernous terdiri atas bundel otot polos yang berelaksasi atau kontraksi saat kopulasi.

Saat dalam keadaan tidak ereksi (Gambar 2A), kaput hemipenis terletak di bagian kaudal, sedangkan pada saat ereksi (Gambar 1A), hemipenis akan keluar dari sisi lateral kloaka, sehingga letak kaput hemipens berpindah di bagian kranial (Mahfud dkk., 2015). Pada kaput hemipenis ditemukan lipatan mukosa (Gambar 1A, 1B) yang ditutup oleh epitel pipih banyak lapis yang di bawahnya ditopang oleh jaringan ikat dengan serat kolagen (Gambar 2B). Gambaran ini berbeda dengan yang ditemukan pada pada ular yang ditutupi oleh tonjolan-tonjolan (papillae) berbentuk seperti duri (Karim, 1998; Porto et al., 2013), agar proses perkawinan berlangsung cukup lama untuk proses fertilisasi (Kardong, 2008; MNH, 2009; Porto, 2013).

Spermatozoa pada kelompok reptilia, disalurkan dari ductus deferens melalui sulcus spermaticus (MNH, 2009). Sulcus spermaticus merupakan saluran lanjutan dari ductus deferens menuju hemipenis, sehingga pada saat kopulasi sperma diejakulasi ke saluran reproduksi betina melalui sulcus spermaticus yang terdapat di dalam hemipenis sebagai organ kopulatori (Kardong, 2008). Saluran ini ditemukan di salah satu sisi luar dinding hemipenis berupa lekukan pada saat ereksi, mulai dari bagian caput sampai radiks hemipenis (Gambar 1A, 1B) (Mahfud dkk., 2015). Dua pembuluh darah juga teramati berjalan bersama-sama di dekat sulcus spermaticus (Gambar 1B, 1C). Saluran seperti ini berbeda strukturnya pada ular. Menurut Kardong (2008), sulcus spermaticus pada ular berbentuk seperti huruf Y karena kedua hemipenis di daerah kaudal menyatu, sehingga sulcus spermaticus ikut menyatu di daerah kaudal.

Saat ereksi, di tengah bagian kaput hemipenis ditemukan penonjolan seperti kepala putik, agak keras dengan konsistensi seperti tendon, dan berwarna putih (Gambar 1A, 1B). Saat dalam keadaan tidak ereksi, jaringan tersebut berada di dasar truncus hemipenis yang berhubungan langsung dengan otot retraktor hemipenis (Gambar 2A). Secara histologis, penonjolan tersebut disusun oleh jaringan ikat dengan serabut kolagen (Gambar 2B), sedangkan otot retraktor hemipenis yang berhubungan langsung dengan hemipenis dan tonjolan tersebut disusun oleh otot lurik (Gambar 2C, 2D). Otot retraktor atau yang biasa dikenal sebagai otot propulsar (Karim, 1998), akan menarik hemipenis kembali ke dalam kantung yang terletak di pangkal ekor setelah kopulasi. Proses ini biasa disebut invaginasi. Selama ereksi, relaksasi otot retraktor menyebabkan masing-masing hemipenis akan keluar melalui lubang di pangkal ekor, yang biasa disebut evaginasi (Kardong, 2008).

\section{Kesimpulan}

Biawak $V$. s. bivittatus memiliki sepasang hemipenis berbentuk tabung (truncus) yang terdapat di pangkal ekor. Mukosa truncus dilapisi oleh epitel 
pipih banyak lapis, ditunjang oleh jaringan ikat padat dan di bawahnya ditemukan corpus cavernous, namun tidak ditemukan jaringan otot seperti halnya pada sebagian reptil dan mamalia pada umumnya. Truncus hemipenis cukup fleksibel untuk memperbesar pada saat ereksi karena corpus cavernous disusun oleh banyak pembuluh darah dan ditopang oleh jaringan ikat.

\section{Ucapan Terima Kasih}

Ucapan terima kasih disampaikan kepada Direktorat Jenderal Pendidikan Tinggi Kementerian Pendidikan dan Kebudayaan Republik Indonesia yang telah membiayai penelitian ini, serta Ibu Rr. Sri Catur Setyawatiningsih, S.Si., M.Si yang telah mendonasikan dua ekor biawak $V$. s. bivittatus jantan sebagai bahan penelitian.

\section{Daftar Pustaka}

Akmal, Y. (2014). Karakteristik morfologi organ reproduksi jantan trenggiling (Manis javanica). Tesis. Program Studi Anatomi dan Perkembangan Hewan. Sekolah Pascasarjana, Institut Pertanian Bogor, Bogor.

Cabral, S. R. P., de Souza, S. L. R., Franco-Belussi, L., Zieri, R., Zago, C. E. S., and de Oliveira, C. (2011). Anatomy of the male reproductive system of Phrynops geoffroanus (Testudines: Chelidae). Acta Scientiarum. Biol. Sc. 33 (4): 487-492. doi: 10.4025/actascibiolsci.V33i4. 8091

Canto, R. D. (2007). Notes on the occurrence of Varanus auffenbergi on Roti Island. Biawak. 1 (1): 24-25.

Goldstein, A. and Padma-Nathan, H. (1990). The microarchitecture of the intracavernosal smooth muscle and the cavernosal fibrous skeleton. J. Urology. 144: 1144-1146.

Gumilang, R., Mardiastuti, A. dan Priyono, A. (2003). Populasi dan penyebaran biawak air asia (Varanus salvator) di suaka margasawa pulau rambut, Jakarta. Dalam: Prosiding Seminar Hasil Penelitian. Bogor, 8 Mei 2003. Bogor: Departemen Konservasi Sumberdaya Hutan Institut Pertanian Bogor. Hlm 163-171.

Jenkins, M. and Broad, S. (1994). International trade in reptile skins: A review and analysis of the main consumer markets, 1983-91 Traffic International Cambridge.

Kardong, K. V. (2008) Vertebrates: Comparative Anatomy, Function, Evolution. $5^{\text {th }}$ ed. McGrawHill. Boston. USA: 565-572

Karim, S. A. (1998). Macroscopic and microscopic anatomy of the hemipenes of the snake Bittis arietans arietans. JKAU: Sci. 10: 25-38.

Kiernan, J. A. (1990) Histological and Histochemiscal Method $2^{\text {nd }}$ ed. Pergamon Press. England.

Mahfud, Nisa', C. dan Winarto, A. (2015). Anatomi organ reproduksi jantan biawak air asia, Varanus salvator (Reptil: Varanidae). Acta Vet. Indones. 3 (1):1-7.

(MNH) Museum of Natural History. 2009. Hemipenes of snakes and lizards. Retrieved from http:// cumuseum.colorado.edu/exhibits/objects/ hemipenes-snakes-and-lizards). Diakses pada tanggal 10 Maret 2013.

Porto, M., de Oliveira, M. A., Pissinatti, L., Rodrigues, R. L., Rojas-Moscoso, J. A., Cogo, J. C., Metze, K., Antunes, E., Nahoum, C. and Mónica, F. Z. (2013). The evolutionary implications of hemipenial morphology of rattlesnake Crotalus durissus terrificus (Laurent, 1768) (Serpentes: Viperidae: Crotalinae). PloS one, 8 (6): 1-8. doi:10.1371/journal.pone.0066903

Prades, R. B., Lastica, E. A. and Acorda, J. A. (2013). Ultrasonography of the urogenital organs of male water monitor lizard (Varanus marmoratus, Weigmann, 1834). Philipp. J. Vet. Anim. Sci. 39 (2): $247-258$.

Rossi, L.F., Luaces, J.P., Marcos A.H. J., Cetica, P.D., Jimeno, G.P. and Merani, M.S. (2012). Anatomy and histology of the male reproductive tract and spermatogenesis fine structure in the lesser anteater (Tamandua 
tetradactyla, myrmecophagidae, xenarthra): Morphological evidences of reproductive functions. Anat. Histol. Embryol. J. Vet. Med. 1-10. doi: 10.1111/ahe.12008

Sever, D.M. (2004). Ultrastructure of the reproductive system of the black swamp snake (Seminatrix pygaea). Iv. Occurrence of an ampulla ductus deferentis. J Morphol. 262: 714-730.

Shine, R., Harlow, P.S. and Keogh, J.S. (1996). Commercial harvesting of giant lizards: The biology of water monitors varanus salvator in southern sumatra. Biol. Conservation. 77: 125134.

Wahyuni, S. (2012). Karakterisasi reproduksi muncak, Muntiacus muntjak muntjak jantan: Kajian anatomi, profil metabolisme testoteron, dan spermatogenesis selama periode pertumbuhan ranggah. Disertasi. Program Studi Biologi Reproduksi. Sekolah Pascasarjana, Institut Pertanian Bogor, Bogor. 